\title{
Marketing Tourism In The Galapagos Islands: Ecotourism Or Greenwashing?
}

Robin M. Self, Alabama State University, USA

Donald R. Self, Auburn University Montgomery, USA

Janel Bell-Haynes, Alabama State University, USA

\begin{abstract}
Tourism accounts for approximately $7.5 \%$ - 15\% of the world's total employment and is the world's most important service industry. In heavily frequented tourist destinations such as the Galapagos Islands in Ecuador, the importance is even higher. International travel is projected to double by 2020 with over 1.5 billion people traveling throughout the world. Within the tourism industry, ecotourism is the fastest growing sector, growing from 10 to 30 percent a year. While exact definitions of ecotourism vary, ecotourism is defined by the International Tourism Society (TIES) as "responsible travel to natural areas that conserves the environment and improves the welfare of local people." A subset of sustainable tourism, ecotourism has a natural area focus, which benefits the environment and communities visited, fosters environmental and cultural understanding, appreciation and awareness. Because there is no universally adopted certification program for ecotourism, tourism operators may market their operations as "ecotourism" while in reality they are "greenwashing." Greenwashers are dishonest tourism operators who embrace ecotourism as a new selling angle. To greenwash is to promote ecotourism while effectively doing the opposite. The Galapagos Islands is a popular destination for ecotourism. Beginning in the late 1960's, the Galapagos tourism industry started with about 1,000 tourists per year and has boomed to 148,000 tourists in 2006. This has caused several problems: growing human population, introduction of alien and invasive species, and unwanted by-products from tourism. As a result, in 2007, the Galapagos Islands were placed on UNESCO's list of World Heritage Sites in Danger. Because of the unique biodiversity of the Galapagos Islands, and the increase in tourism and its negative consequences, the Galapagos Islands presents an excellent example for a case study in marketing of ecotourism. Using the criteria established by the Mohonk Agreement for responsible ecotourism, this paper examines the websites of ecotourism operators in the Galapagos Islands to determine the extent to which they are "ecotours" or "greenwashed tours." The implications for conservation of the islands and responsible marketing are discussed.
\end{abstract}

Keywords: ecotourism, tourism marketing, greenwashing, Galapagos Islands

\section{INTRODUCTION}

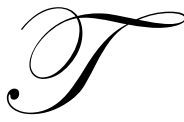

ourism accounts for approximately $7.5 \%-15 \%$ of the world's total employment and is the world's most important service industry (USAID Launches Ecotourism, 2008; Hickman, 2006; Schumacher, 2007). In heavily frequented tourist destinations such as the Galapagos Islands in Ecuador, the number is even higher. International travel will double by 2020 (USAID Launches Ecotourism, 2008) with over 1.5 billion people traveling over the earth (Responsible Tourism, 2007).

Worldwide tourism receipts, as measured in constant U.S. dollars, rose $8.4 \%$ between 2005 and 2006, to reach an estimated record value of $\$ 735$ billion. Europe commanded the largest share of international arrivals in 2006 with an estimated 456.9 million, or 54.3\% of the world total. Asia and the Pacific posted the second-largest share of international tourist arrivals (19.9\%), with an estimated 167.4 million arrivals in 2006 (Tourism Trends, 2008). 
Within the tourism industry, ecotourism is the fastest growing tourism sector (Cox, 2007) particularly among baby boomers and travelers who want to feel confident that they are participating in responsible and ethical travel (Elston, 2007). The World Tourism Organization estimates that ecotourism is growing up to seven times faster than the rest of the tourism segment (Ecotourism, 2009), while Clayton (2004) suggests the segment may be growing 10 to 30 percent faster than other travel. Together, nature tourism and ecotourism make up about $20 \%$ of international tourist travel.

What, then, is ecotourism? How does it differ from other forms of tourism? What makes ecotourism so attractive to current travelers? Given the high volume of ecotourists, are there any downsides to ecotourism? This paper addresses these issues and applies them to the Galapagos Islands as a case study in ecotourism.

\section{ECOTOURISM}

\section{History of Ecotourism}

Even though the term "ecotourism" is relatively new, the concept has been around since at least the $19^{\text {th }}$ century. Major national parks and wilderness areas were often first established in countries such as Australia, New Zealand and the United States because of sustained political pressure from hikers, bushwalking clubs and individuals who wished to preserve large (and often remote sites) for minimal impact recreation and tourism (Mercer, 1996).

Mercer (1996) contends that the term ecotourism was coined in 1965 as part of eco-development, which focused primarily on the rural aspects of development which held that proposed land-use changes should always be alert to the carrying capacity of local ecosystems. The term resurfaced in the 1980's and referred to travel that included any aspect of nature. Later, tourism entrepreneurs developed it further to attract tourists in new areas, away from the beaches, museums, and cities.

The first mention of ecotourism in the English-language academic literature was by Romeril in 1985. In the 1990's the tourism industry realized the profit potential of ecotourism and the term "eco" was used by travel agents to market their tour packages. Eventually, ecotourism organizations such as the International Ecotourism Society (TIES) and the Ecotourism Society (TES) were formed (Travel and tourism, 2005). While some may use the term "ecotourism" as being synonymous with "nature tourism," "adventure tourism," "responsible tourism," "ethical tourism," and "green tourism", ecotourism does have specific characteristics that differentiate it from these segments of the tourism industry.

\section{Definition of Ecotourism}

A subset of sustainable tourism (tourism that actively aims to reduce negative impacts of tourism in both the present and the future), ecotourism is defined by TIES as "responsible travel to natural areas that conserves the environment and improves the welfare of local people" (Constantineau, 2007; Kuchment, 2008). The World Conservation Union defines ecotourism as "environmentally responsible travel and visitation to relatively undisturbed natural areas, in order to enjoy and appreciate nature (and any accompanying cultural features-both past and present) that promotes conservation, has low visitor impact, and provides for beneficially active socio-economic involvement of local populations" (Stem, Lassoie, Lee \& Deshler, 2003, p. 323).

Because of the proliferation of the use of the term "ecotourism" in tourism advertising, industry groups in different countries have adopted definitions of ecotourism to protect the reputation of the tourism industry. For example, the Travel Industry Associations of Canada (TIAC) adopted the following definition: "Ecotourism is a segment of sustainable tourism that offers experiences that enable visitors to discover natural areas while preserving their integrity, and to understand, through interpretation and education, the natural and cultural sense of place. It fosters respect toward the environment, reflects sustainable business practices, creates socioeconomic benefits for communities/regions, and recognizes and respects local and indigenous cultures, traditions, and values" (Goeldner \& Ritchie, 2009, p. 484). 


\section{Principles of Ecotourism}

Researchers (Powell \& Ham, 2008; Ghanaian Chronicle, 2006; Schumacher, 2007; Mercer, 1996; Wallace $\&$ Pierce, 1996) agree that ecotourism programs should encompass the following six characteristics:

\section{Environmental Conservation}

Programs should minimize the adverse effects of traditional tourism on the natural environment. Hospitality providers should promote recycling, energy efficiency, and water re-use, and should avoid negative impact that can damage or destroy the integrity or character of the natural or cultural environment being visited. Tours should maintain ecological resource integrity through low-impact, non-consumptive resource use to preserve natural resources and biodiversity (Stem, et al., 2003).

Additionally, ecotourism should build a constituency to promote conservation and provide an impetus for private conservation efforts. Under such circumstances, conservation benefits can extend beyond the immediate experience of the ecotourism venture, as ecotourists become active advocates for conservation in the area visited, as well as in their home towns or countries (Stem, et al., 2003). This advocacy can help in several ways. First, ecotourists are more likely to give more generously for the conservation of the area. Second, they can also donate their time for lobbying in favor of policies that help conservation (Batta, 2006).

\section{Cultural Integrity}

The program should enhance the cultural integrity of local people and involve people in natural and cultural systems (Batta, 2006). The ecotourism product should be respectful of and sensitive to local cultures. Local people and experts should be consulted so that cultural values are treated appropriately and that legitimate needs of local people are met while depicting their culture (L'Express, 2006).

\section{Education}

Because appreciation and education are the main motives for traveler participation, both tourists and local people should be educated on the importance of conservation. It should teach travelers something about the environment, the wildlife and the local area. This implies a high level of preparation from both tour leaders and participants. The program should provide special opportunities to the employees and local people to learn more about their area and interpretation should be a key component of the ecotourism product (Batta, 2006).

\section{Contributes to the Local Economy and Communities}

Programs should provide creation of economic opportunities for local communities to direct revenues to local people living adjacent to protected areas. This rationale is driven by the assumption that local communities are most likely to protect or maintain a resource base in a form that is suitable for tourism if they stand to benefit from it (Blamey, 2001, p. 13). Potentially, tourist expenditures can provide much needed finances for receiver countries and depressed rural regions (Mercer, 1996).

Under ideal circumstances, ecotourism provides employment, improved infrastructure, and increased business for local stores, especially when local residents are involved in its management and operations and community partnerships are developed. Local suppliers are the key if the economic and social benefits associated with ecotourism contribute to rural development. Successful businesses make for a stronger ecotourism sector which will help host communities obtain great benefits from ecotourism (Silva \& McDill, 2004). Because ecotourism brings people closer to local markets, it can be an important low-cost mechanism for local businesses and artisans to market and sell their goods (Stem, et al., 2003).

\section{Generates Money to Finance Conservation}

Programs should direct revenues to the conservation of natural areas and the management of protected 
areas. Also, programs should emphasize the need for planning and sustainable growth of the tourism industry and seek to ensure that tourism development does not exceed the social and environmental "capacity" of the area. Ecotourism should financially support protected areas through tourism-related park fees (Stem, et al., 2003; Batta, 2006).

\section{Ecotourism versus Nature Tourism}

While some travelers use the terms "nature tourism" and "ecotourism" interchangeably, differences exist between these two segments of the industry as presented in Table 1.

Table 1: Nature Tourism versus Ecotourism

\begin{tabular}{|l|l|l|}
\hline \multicolumn{1}{|c|}{$\begin{array}{l}|c| \\
\text { Focus (Honey \& Stewart, } \\
\text { 2002) }\end{array}$} & What travelers do & $\begin{array}{l}\text { Ecotourism } \\
\text { country }\end{array}$ \\
\hline $\begin{array}{l}\text { Management Decisions } \\
\text { (Stem, et al., 2003) }\end{array}$ & Based on Utilitarian values & $\begin{array}{l}\text { Based on Nature's intrinsic values, community } \\
\text { self-determination \& participation }\end{array}$ \\
\hline Education (Adamson, 2005) & $\begin{array}{l}\text { Does not contain an educational } \\
\text { component }\end{array}$ & $\begin{array}{l}\text { Educational is a significant component and } \\
\text { teaches travelers about the environment, the } \\
\text { wildlife and the local area }\end{array}$ \\
\hline $\begin{array}{l}\text { Motivation for } \\
\text { participation (Powell \& } \\
\text { Ham, 2008) }\end{array}$ & Entertainment, comfort \& consumption & Appreciation and education \\
\hline $\begin{array}{l}\text { Type of Participation (Kim, } \\
\text { 2009) }\end{array}$ & Passive participation through scenery & $\begin{array}{l}\text { Active participation through experience } \\
\text { oriented characteristics }\end{array}$ \\
\hline $\begin{array}{l}\text { Conservation Emphasis } \\
\text { Leach, 2004) }\end{array}$ & $\begin{array}{l}\text { Travel in the environment without a } \\
\text { conservation dimension }\end{array}$ & $\begin{array}{l}\text { Low or zero impact travel with focus on } \\
\text { environmental conservation }\end{array}$ \\
\hline $\begin{array}{l}\text { Size of tour \& guide (Kim, } \\
\text { 2009) }\end{array}$ & $\begin{array}{l}\text { No limit on participation, no } \\
\text { guide/interpreter required }\end{array}$ & $\begin{array}{l}\text { 20 members or less with on-site education and } \\
\text { interpreter/guide }\end{array}$ \\
\hline $\begin{array}{l}\text { Area visited (Thomson } \\
\text { 2000) }\end{array}$ & Natural area & Protected area \\
\hline
\end{tabular}

\section{Who are Ecotourists?}

- $\quad$ Ecotourists tend to be between 35-54 years old (although age varied with activity and other factors such as cost) (www.ecotourism.com). Dolnicar, Crouch and Long (2008) report 5 studies showing ecotourists are middle aged, while 2 studies report ecotourists as being older.

- Women slightly outnumber males, although differences exist by activity (Sinclair, 2009; www.worldtourism.org).

- $\quad$ They are more highly educated than the general tourist population (Sinclair, 2009; www.world-tourism.org; Dolnicar, et al., 2008; Kwan, Eagles, \& Gebhardt, 2008). According to TIES, 82\% are college graduates (www.ecotourism.com).

- $\quad$ Ecotourists are in a higher income bracket and spend more money per trip than other tourists (www.worldtourism.org; Dolnicar, et al., 2008; Kwan, et al., 2008; Kaplan, 2009; Mitchell, 2008).

- Ecotourists have high levels of environmental commitment, support enhanced sustainability, want physically active and challenging experiences, travel in small groups, take longer trips, demand fewer services, make their own travel arrangements, and are more active in their search for information than general tourists (Kwan, et al., 2008).

\section{GREENWASHING}

A 2007 survey conducted by The Travel Industry Association has documented that ecofriendly travel has grown more popular: 78\% of Americans consider themselves environmentally conscious (Powell \& Ham, 2008), more than three quarters of American travelers feel it is important that their visits not damage the environment, $62 \%$ say it is important to learn about other cultures when they travel, and $38 \%$ of travelers say they would pay more to 
use a travel company that strives to protect and preserve the environment (Goeldner \& Ritchie, 2009).

Green travel is the current rage and has gone from a trend to a part of mainstream consumer and corporate culture (Beam, 2007; Kuchment, 2008; Pfeiffer, 2009). This increase in ecofriendly travel has some organizations worrying that the meaning of "ecotourism" is being watered down and is simply used as a marketing tool to take advantage of increased demand in order to boost revenue (Powell \& Ham, 2008; Chenu, 2007; Cox, 2007). Because of the lack of standardization and labeling in using the term "eco" as it relates to tourism, "it seems that any company offering an experience in the great outdoors can simply add the word eco-tourism to its advert or brochure; whether the holidays live up to the name is another matter" (Baker, 2005, para 2).

The tourism industry has tried to address these certification concerns; over 100 certification or "eco" labeling programs exist with different standards and criteria. In an effort to reach industry consensus, The Mohonk Agreement, drafted in 2000 at an international workshop on Ecotourism and Sustainable Tourism Certification, is a two-tiered framework with criteria for certification in sustainable tourism and ecotourism (Medina, 2005). The criteria from the Mohonk Agreement for ecotourism are as follows:

- $\quad$ Focus on personal experiences of nature to lead to a greater understanding and appreciation

- Interpretation and environmental awareness of nature, local society and culture

- $\quad$ Positive and active contributions to conservation of natural areas or biodiversity

- $\quad$ Economic, social, and cultural benefits for local communities

- $\quad$ Fostering of community involvement, where appropriate

- $\quad$ Locally appropriate scale and design for lodging, tours and attractions

- Minimal impact on and presentation of local (indigenous) culture

These criteria for international standards, however, are not mandatory, leaving the industry open to greenwashing. "Greenwashers" are dishonest tourism operators who embrace ecotourism as a new selling angle. To greenwash is to promote ecotourism while effectively doing the opposite (Fosbery, 2006). According to Constantineau (2007), many ecotours are just ordinary operations that "greenwash" themselves by embracing the tourism label while doing little to act in an environmentally responsible manner. Weaver (2002) argues that greenwashers give the appearance of ecotourism (nature-based, learning-focused, environmentally and socioculturally responsible) without the substance of sustainability. Because ecotourism is growing fastest in developing countries with the weakest regulations (but some of the most stunning environments), strong standards are needed to minimize greenwashing (Clayton, 2004).

\section{Is it "Ecotourism or is it "Greenwashing"?}

How can one differentiate between ecotourism and greenwashing? Constantineau (2007), Adamson (2005), Pfeiffer (2009), and Ecotourism Credentials (2007) suggest asking the following questions to assess whether a venture is a "real" ecotour or a "greenwashing" operation:

- What sustainable practices do they engage in? What are their policies concerning restricting visitor numbers, recycling and storing water, being energy self-sufficient, reducing and disposing of waste?

- $\quad$ Do they offer interpretive guiding and other educational opportunities?

- $\quad$ Do they purchase carbon offsets?

- $\quad$ Do they hire local employees?

- Are tours operations locally owned?

- What is its environmental policy?

- What do they do to protect native wildlife and flora?

- Does it practice "leave no trace" on the trail?

- Are there educational programs to inform the visitors about the area, its wildlife (how close you can get), the culture and history?

- Does it provide financial support for local conservation, revegetation, etc.?

- Is there cooperation with the National Parks and Wildlife Service and/or the local council? 
- Does it submit to a performance-based audit by an independent party?

- Is there a set number of tourists per tour?

- Does it have any "ecotourism" certification?

- Does it have environmental guidelines for its employees to follow in their day-to-day work?

- $\quad$ Are they listed on the TIES website?

\section{NEGATIVE ASPECTS OF ECOTOURISM}

Successful ecotourism attracts more tourists, which brings more traffic and increases negative impacts. Such impacts could seriously threaten the resources upon which ecotourism depends (Stem, et al., 2003; Clayton, 2004). Every successful enterprise wants to grow, so the difficulty for ecotourism operators is knowing at what point they should stop trying to expand. Ecotourism is supposed to have zero environmental impact, but there's an argument that it could be the thin end of the wedge - that once you find an attraction and people want to come, then you are really opening up an area for mass marketing tourism (Adamson, 2005). The following problems have been associated with ecotourism:

\section{Lack of Economic Benefits}

Research suggests that ecotourism often fails to provide widespread economic benefits. Many scholars question ecotourism's contributions to local development, asserting that little or no ecotourism revenue reaches local people (Stem, et al., 2003). Stronza and Pegas (2008) report that some ecotourism projects have not generated sufficient economic benefits to build incentives for conservation among host communities, and ecotourism enterprises may also create relatively few jobs relative to the number of local residents.

\section{Adverse Impact on Animals}

From watching whales in New England to tracking polar bears on the tundra to swimming with dolphins in the Pacific, well-meaning tourists are putting pressure on animals worldwide. In some cases, ecotourism unwittingly appears to be killing the wildlife it seeks to protect (Clayton, 2004).

\section{Adverse Environmental Impact}

Successful ecotourism may bring in higher numbers of tourists leading to habitat disturbance and forest degradation resulting from trail erosion. Both civic (roads, drainage, and sewage) and tourism-specific (hotels, parking, airports, etc.) infrastructure requires land, which is often made available by clearing forests causing soil erosion, and change in land use. Increased activity and consumption may lead to rapid depletion of renewable and non-renewable natural resources such as construction materials, forests, and water (Batta, 2006). Ecotourism must also deal with the carbon emission issue; travelers must get to the ecotourism site, which involves both long haul and short flights (Cox, 2007). Travel related activities account for up to one third of greenhouse emissions that affect global warming. Every time a traveler flies, his/her portion of the flight emits nearly a ton, on average, of greenhouse gasses (Natural Habitat Adventures, 2009).

\section{ECOTOURISM IN THE GALAPAGOS ISLANDS}

Located 600 miles west of the Pacific Coast of Ecuador, the Galapagos Islands was established as an Ecuadorean National Park in 1959, a World Heritage Site in 1978, and a UNESCO Man and the Biosphere Reserve in 1984 (Brazil, 2000). The Islands are managed by the Ecuadorian government as the Galapagos National Park (GNP). The Galapagos National Park consists of 120 islands, has an approximate land area of 8,000 square kilometers and is home to many endemic species. The waters around the volcanic archipelago host over 3,000 species of fish and many charismatic marine mammals, including fur seals, sea lions, dolphins and whales (Powell $\&$ Ham, 2008). Only two of the islands in the Galapagos are inhabited: Isabela, the largest of the group, and San Cristobal (Ecuador Tourism, 2009). 
Beginning in the late 1960 's, the organized Galapagos ecotourism industry started with about 1,000 tourists per year. During the 1980s, tourism boomed and the number of tourists increased from 41,000 in 1990 to 180,000 in 2008 (Galapagos and you, 2009; Nash, 2009). The Galapagos tourism experience is both marine and terrestrial. Currently over 68 vessels are licensed by the Galapagos National Park to provide tourists with transportation and lodging while cruising the archipelago (Powell \& Ham, 2008).

\section{Problems with Tourism in the Galapagos Islands}

The Galapagos Islands have been a well organized and managed ecotourism destination, but in recent years there have been growing tendencies towards greenwashing and conventional tourism, which put in danger the biodiversity of the islands (Galapagos and You, 2009). While ecotourism in the Galapagos has helped the Galapagos National Park to gain funds for its management for scientific research and for conservation projects (and is the only practical way to support the park), it has also brought some problems to the archipelago. In 2007, the Galapagos were included in the Danger List of the UNESCO World Heritage Sites- the main reason is the uncontrolled development of tourism and the failure of various institutions and agencies to deal with these threats (Nash, 2009).

\section{Growing Human Population}

Although 97\% of the area within the Galapagos National Park are protected, there are problems of growing human population with rapid and unorganized growth of civic infrastructure. Since the 1970s, when ecotourism started expanding in the Galapagos Islands, the islands have had an unsustainable growth rate of 6 to $10 \%$ per year (Powell \& Ham, 2008). Over the past few decades the population has increased over 300\% (Galapagos and you, 2009).

Tourism was one of the main reasons that during the 1990s the Galapagos was one of the fastest-growing regions of Ecuador and the world as immigrants from mainland Ecuador sought to take advantage of the higher standard of living in the Islands (Brazil, 2000). Nash (2009) reports that each $\$ 3,000$ spent by tourists pulls in one more Galapagos immigrant. With only $3 \%$ of the islands set aside for human settlement, there is little room for people and little for them to do except fish which leads to other problems as well (Conservation Challenges in the Galapagos, 2009).

\section{Resource Usage}

The tourism boom from the 1970s to the present, coupled with immigration to the Galapagos Islands and its unsustainable management, has led the Galapagos to face conflicts over limited resources. The increased demand for fresh water, electricity, telephone service, land and schools which at the same time require more fuel for electricity, water desalination, garbage and sewer disposal, cars and boats are just some of the effects of population growth in the islands (Galapagos and you, 2009).

\section{Alien and Invasive Species}

From pirates and whalers to modern tourists, humans have introduced plants and animals from the outside world. Introduced plant species, now outnumbering native species, represent a major problem as they compete with native vegetation, taking over habitats more quickly than the native vegetation can adapt to them. Introduced species number over 740 (most are plants, some are animals such as feral goats, pigs, and cats) (Su, 2002; Nash, 2009). Herbivores such as goats compete with native tortoises and iguanas, making food less available and destroying native vegetation. Although the National Park and Charles Darwin Station have worked to remove invasive species, the rapid growth of population and tourism (with its uninspected transport and cargo boats) makes this the most worrisome environmental threat in the Galapagos (Galapagos and you, 2009; Nash, 2009). The rapid development of the ecotourism market has threatened the islands' pristine and distinctive natures. 


\section{Environmental Impacts}

Unwanted by-products from irresponsible tourism such as contamination from boat paint and engines, oil spills, and overused sites are a serious problem. Waste production from industrialization and the development of settlements and in air pollution from the numerous motor vehicles that cater mainly to tourists have a negative environmental impact ( $\mathrm{Su}, 2002)$. The large increase in the numbers of tourists has resulted in erosion along sensitive trails, plant and animal disturbance, and a general decline in the quality of the tourism experience (Stem, et al., 2003).

Global warming and ocean acidification are also a problem. An estimated 850,000 gallons of diesel and gasoline fuel are shipped to the Galapagos each month, mostly to power the cruise boats and electric power generators. Groundwater supplies on the inhabited islands are inadequate and increasingly polluted by sewage (Nash, 2009).

\section{Improving Ecotourism in the Galapagos Islands}

Most research on ecotourism involves case studies of impacts on local communities, natural resources, and conservation. Areas studied include Brazil and Peru (Stronza \& Pegas, 2008), Asia, (Weaver, 2002), India (Batta, 2006), Belize (Medina, 2005), Indonesia (Clifton \& Benson, 2006) Costa Rica (Gray \& Campbell, 2007), and the Galapagos Islands (Powell \& Ham, 2008). While the research locations vary, conclusions are applicable to ecotourism in the Galapagos Islands.

\section{Legislation}

In 1998, the Ecuadorian government passed the "Special Law for the Galapagos" that limits immigration to the islands and appropriates more revenues from the tourism industry directly into conservation efforts. Now, up to $50 \%$ of all financial gains from National Park fees are reinvested into attempts to conserve the islands (Galapagos and you, 2009).

\section{Tour Design and Interpretation}

Proponents of ecotourism within protected areas, such as the Galapagos Islands, believe that tour design and interpretation can help mitigate the negative impacts of tourism (human and environmental), and build educated and motivated stakeholders that support environmental conservation and social improvements to ensure a sense of personal stake in the Galapagos.

Powell and Ham (2008) found that a well-designed and delivered interpretation during the ecotourism experience resulted in increased knowledge of the host-protected area, supportive attitudes toward resource management issues facing the host-protected area, general environmental behavioral intentions and philanthropic support of conservation.

Other suggestions include limiting ecotourism activities to designated parts of parks and natural protected areas and implementing strict rationing of visitor use (Mercer, 1996). Adamson (2005) recommends certifying both the operators and the ecotourists with stringent guide training and licensing processes paired with control and management at the local level.

\section{Lessening Environmental Impact}

Recycling cooking oil to make biodiesel, installing a waste-water system that produces clean effluent, using compact fluorescent bulbs, recycling food and beverage containers, and using homemade food to reduce the need for pre-packaged food are all effective techniques to lessen environmental impacts of tourism (Constantineau, 2007). 


\section{INTERNET MARKETING OF TOURISM PACKAGES}

One major change in the travel industry is the increased use of the internet both to find information about travel companies and tours, and to purchase the trip on line. Customers increasingly favor a simple click to book a trip. The growing popularity of price comparison sites and meta search engines is putting more pressure on travel agents' ability to root out the best deal for a customer (May, 2006). According to Forrester Research, four out of five "online Americans" take at least one leisure trip per year and 59\% of U.S. online leisure travelers are "bookers," web tourists who research and buy online; they book 57\% of their trips online. This trend is not limited to younger, internet-savvy tourists; especially noteworthy are travelers over age 55 who now embrace web travel in a meaningful way (Travel Agents Despair, 2006).

Weir believes that online marketing is the most important avenue to reach potential responsible travelers particularly as they are more inclined to do their research, talk to other travelers, and book directly (Special Report: Travel Marketing, 2006). The rise of online travel information has made people think and behave differently about the way they travel. A 2008 survey found that four in ten British online adults say the Internet has changed their traveling behavior. Some of the common ways in which the Internet has impacted behavior include decisions on what places to visit (the internet has opened the doors for less traditional forms of travel), whether to make travel more fun, or to increase the number of trips taken (Shaddick, 2008). Additionally, more consumers are using the internet to look for eco-credentials before making travel choices (Ketchell, 2007).

How then, does an environmentally concerned traveler make informed judgments about the marketing claims of travel packages that use the label "ecotourism" and purport to be environmentally sound, economically helpful to the local community, and ethical? What should they look for in their websites?

\section{METHODOLOGY}

Replicating the methodology used by Choo and Jamal (2009), a content analysis was performed on websites of ecotourism operators. Internet search engines (Google, Yahoo, bing) were used to identify ecotourism cruise operations in the Galapagos islands using the search times "ecotourism" and "Galapagos Islands." "Adventure" tours and "nature" tours were not used as search terms. As of November 1, 2009, fifteen company websites identified themselves as "ecotours" in the Galapagos Islands. The websites were evaluated using the following criteria (in bold) developed from the Principles of Ecotourism and the Mohonk Agreement:

- $\quad$ Focus on personal experiences of nature to lead to a greater understanding and appreciation

$\circ \quad$ First-hand experience?

- Interpretation and environmental awareness of nature, local society and culture

$\circ \quad$ Is there an interpretive guide?

- Are there educational opportunities to learn about nature, Ecuadorian society and culture?

- Does the company have an environmental policy?

$\circ \quad$ Are measures in place to protect wildlife and flora?

- Does the company practice "leave no trace"?

- Positive and active contributions to conservation of natural areas or biodiversity

- Does the company contribute to local conservation organizations?

- $\quad$ Economic, social, and cultural benefits for local communities

- $\quad$ Fostering of community involvement, where appropriate

- Does the company hire local employees?

- Does the company provide economic benefits for locals?

- Does the company provide socio-cultural benefits for locals?

- $\quad$ Minimal impact on and presentation of local (indigenous) culture

- Locally appropriate scale and design for lodging, tours and attractions

$\circ \quad$ Is the number of visitors per tour restricted?

- What sustainable practices does the company engage in?

$\circ$ Are home office environmental practices identified on the website? 
Does the company purchase carbon offsets or have a carbon neutral policy?

- Does the company recycle?

$\circ \quad$ Does the company attempt to minimize waste?

$\circ$ Does the company engage in energy self-sufficiency practices?

$\circ \quad$ Is there a performance based audit for eco-certification?

Additionally, the home country of the tour operation, the type of social media used on the website as a marketing tool (Facebook, newsletter, blog, etc.), and the average price of the tour, were identified. In calculating the average price of the tour, the following costs were not included in the calculations: international airfare to Ecuador, in-country air fare to the Galapagos Islands, fuel surcharges, \$100-per-person fee to the Galapagos National Park, and any extra amenities offered on board. Prices quoted on the websites were for double occupancy and were the lowest prices listed for the cruise. The prices reported are calculated on a per-day basis.

\section{RESULTS}

Table 2 presents price information of tours by country. Ecuadorian tour operators offered tours at lower prices than those offered by UK or USA operators.

Table 2: Average Per-day Price of a Galapagos Island Cruise

\begin{tabular}{|l|c|c|c|}
\hline \multicolumn{1}{|c|}{ Country } & & Average per-day price & Range \\
\hline Ecuador & 5 & $\$ 281.32$ & $\$ 212.70-\$ 417.85$ \\
\hline UK & 2 & $\$ 389.83$ & $\$ 327.20-\$ 452.46$ \\
\hline USA & 8 & $\$ 449.04$ & $\$ 325.70-\$ 602.30$ \\
\hline Sample & 15 & $\$ 385.24$ & $\$ 212.70-\$ 602.30$ \\
\hline
\end{tabular}

As seen in Table 3, all of the tour operators offer a first-hand experience, provide an interpretive guide, and restrict the number of visitors per tour or activity. This is not surprising because, unlike other destinations, the Galapagos National Park requires tour operators to accompany tourists within the park and limits the number of visitors per tour.

All of the UK and USA tour operators offered educational opportunities for their guests, while only two of the Ecuadorian operators identified educational opportunities on the websites. Educational opportunities included the following types of articles and information on the website: environmental issues, conservation in general, conservation in the Galapagos Islands, ecotourism principles, responsible travel, advice for the responsible traveler, flora and fauna in Ecuador, history of the Galapagos Islands, and cultural information about Ecuador. Other opportunities included lectures and briefings by the guides, trips to the Interpretation Center in San Cristobal, and reading lists.

Table 3: Variables by Country

\begin{tabular}{|l|c|c|c|c|c|c|c|c|}
\hline Country & $\begin{array}{c}\text { First- } \\
\text { hand }\end{array}$ & Guide & $\begin{array}{c}\text { Restrict \# } \\
\text { of visitors }\end{array}$ & $\begin{array}{c}\text { Educational } \\
\text { Opp. }\end{array}$ & $\begin{array}{c}\text { Environment } \\
\text { policy }\end{array}$ & $\begin{array}{c}\text { Protect } \\
\text { flora } \\
\text { \& fauna }\end{array}$ & $\begin{array}{c}\text { Leave } \\
\text { no trace }\end{array}$ & $\begin{array}{c}\text { Financial } \\
\text { contribution } \\
\text { to conservation }\end{array}$ \\
\hline Ecuador & $100 \%$ & $100 \%$ & $100 \%$ & $40 \%$ & $100 \%$ & $60 \%$ & $0 \%$ & $40 \%$ \\
\hline UK & $100 \%$ & $100 \%$ & $100 \%$ & $100 \%$ & $50 \%$ & $50 \%$ & $0 \%$ & $100 \%$ \\
\hline USA & $100 \%$ & $100 \%$ & $100 \%$ & $100 \%$ & $62 \%$ & $38 \%$ & $38 \%$ & $75 \%$ \\
\hline Sample & $100 \%$ & $100 \%$ & $100 \%$ & $80 \%$ & $73 \%$ & $47 \%$ & $20 \%$ & $67 \%$ \\
\hline
\end{tabular}

One hundred percent of the Ecuadorian tour operators provided a general environmental policy on their web site, while $62 \%$ of the American-based companies and $50 \%$ of the UK companies provided a policy. Only $38 \%$ of the American-based companies provided specific measures in place to protect wildlife and flora on the trip; half of the UK companies identified measures, and $60 \%$ of the Ecuadorian companies identified practices in place on tours to protect flora and fauna. Only 3 (all from the USA) of the 15 companies in the sample included the "Leave 
No Trace" policy on their website. Sixty-seven percent of the total sample indicated that they made financial contributions to conservation organizations, but these were not necessarily dedicated to conservation in the Galapagos Islands.

Table 4 presents information on benefits to the host country and energy practices.

Table 4: Host Country Benefits and Energy Practices

\begin{tabular}{|l|c|c|c|c|c|c|c|}
\hline Country & $\begin{array}{c}\text { Hire Local } \\
\text { Employees }\end{array}$ & $\begin{array}{c}\text { Economic } \\
\text { Benefits to } \\
\text { Locals }\end{array}$ & $\begin{array}{c}\text { Socio-cultural } \\
\text { Benefits to } \\
\text { Locals }\end{array}$ & $\begin{array}{c}\text { Home office } \\
\text { Sustainability } \\
\text { Practices }\end{array}$ & $\begin{array}{c}\text { Carbon } \\
\text { Offsets }\end{array}$ & $\begin{array}{c}\text { Recycling } \\
\text { practice energy } \\
\text { self-sufficiency }\end{array}$ \\
\hline Ecuador & $60 \%$ & $60 \%$ & $20 \%$ & $20 \%$ & $40 \%$ & $20 \%$ & $40 \%$ \\
\hline UK & $100 \%$ & $100 \%$ & $0 \%$ & $0 \%$ & $100 \%$ & $50 \%$ & $50 \%$ \\
\hline USA & $75 \%$ & $75 \%$ & $13 \%$ & $25 \%$ & $38 \%$ & $50 \%$ & $38 \%$ \\
\hline Sample & $73 \%$ & $73 \%$ & $20 \%$ & $20 \%$ & $47 \%$ & $40 \%$ & $40 \%$ \\
\hline
\end{tabular}

Companies from all three countries indicated that they hired local employees: UK, 100\%; USA, 75\%; and, Ecuador, 60\%. These same percentages held for the next variable - "providing economic benefits to locals. However, the percentage drops when referring to socio-cultural benefits for the local communities (13\% for the overall sample). This is more than likely due to the cruise nature of the activity where the attention is focused on wildlife and visiting the $97 \%$ of the park that is uninhabited (except for wildlife).

Only $20 \%$ of the companies' websites included sustainability or environmental policies and practices for their home office. Home office practices include reusing paper (material is printed on 50\% recycled paper and 30\% post consumer content using soy ink), buying products in bulk, and purchasing high quality, long-lasting equipment. Some companies recycle everything in the home office that can be recycled such as paper, plastic, glass, ink cartridges, furniture and computers.

Almost half of the sample (47\%) purchased carbon offsets or engaged in carbon neutral policies. Forty percent of the sample indicated that they practiced recycling on the cruise, tried to minimize waste, and engaged in practices to become energy self sufficient. Only one of the companies (from Ecuador) has eco-certification through a performance-based audit, and one American company is looking into outside certification.

Two-thirds of the tour operations reported membership, affiliations and partnerships with agencies such as the Rainforest Alliance, the International Galapagos Tour Operators Association, and the Ecuadorian Association of Ecotourism. Only $20 \%$ of the sample indicated membership in the International Ecotourism Society (TIES) on their website, as seen on table 5 .

Table 5: Certifications and memberships

\begin{tabular}{|l|c|c|c|}
\hline \multicolumn{1}{|c|}{ Country } & Performance based audit & $\begin{array}{c}\text { Memberships \& } \\
\text { Certifications }\end{array}$ & TIES Member \\
\hline Ecuador & $20 \%$ & $60 \%$ & $20 \%$ \\
\hline UK & $0 \%$ & $100 \%$ & $0 \%$ \\
\hline USA & $0 \%$ & $63 \%$ & $25 \%$ \\
\hline Sample & $7 \%$ & $67 \%$ & $20 \%$ \\
\hline
\end{tabular}

Table 6 presents information concerning media use.

Table 6: Media Use

\begin{tabular}{|l|c|c|c|c|c|c|c|}
\hline Country & Overall Media Use & Facebook & Blogs & Newsletters & Live chat & Pod casts & Twitter \\
\hline Ecuador & $20 \%$ & $20 \%$ & $0 \%$ & $0 \%$ & $20 \%$ & $0 \%$ & $20 \%$ \\
\hline UK & $100 \%$ & $50 \%$ & $50 \%$ & $100 \%$ & $50 \%$ & $50 \%$ & $0 \%$ \\
\hline USA & $88 \%$ & $25 \%$ & $50 \%$ & $63 \%$ & $13 \%$ & $0 \%$ & $13 \%$ \\
\hline Sample & $67 \%$ & $27 \%$ & $33 \%$ & $47 \%$ & $20 \%$ & $7 \%$ & $13 \%$ \\
\hline
\end{tabular}


Overall, $67 \%$ of the sample used some type of media to communicate with potential clients. Traditional media such as newsletters were used more than newer media such as Facebook, Twitter, blogs, and podcasts.

\section{DISCUSSION}

This study examined the extent to which websites of ecotours in the Galapagos Islands reflect the principles of ecotourism (as advanced by the Mohonk Agreement) or engaged in greenwashing practices.

The first principle - a focus on personal experiences of nature to lead to a greater understanding and appreciation - was evident on $100 \%$ of the websites. The websites all stressed a first-hand experience interacting with animals and experiencing nature in a wide variety of settings. Testimonials and pictures from previous clients attested to the close interaction with nature.

Results are mixed on the second principle which focuses on interpretation and environmental awareness of nature, local society and culture. All tours offered an interpretive guide, and $80 \%$ of the companies mentioned a variety of educational opportunities ranging from structured lectures and briefings to reading lists and conservation articles. Given the nature of the tour - cruising within the mostly uninhabited Galapagos islands - the educational opportunities focused on wildlife and flora rather than on Ecuadorian society and culture.

Three-fourths of the total sample provided an environmental policy on their websites, with $100 \%$ of the Ecuadorian websites listing a policy. This is in line with Stronza and Pegas'(2008) research which found that local tour operators versus private/chain operators promote more effective conservation in host destinations. However, the operators may be greenwashing in that less than half of the sample $(47 \%)$ provided specific measures in place to protect wildlife and flora, and only $20 \%$ of the websites said they followed a "leave no trace" policy. Given the fragility of the Galapagos Islands, ecotour operators should provide specific measures on their websites for their travelers to protect both the animals they encounter and the island themselves.

The majority of the websites in the sample (67\%) indicated that they made financial contributions to local conservation organizations, which is the third principle of ecotourism.

Tourism operators are required to provide economic, social, and cultural benefits for local communities and foster community involvement, where appropriate. Three-fourths of the websites had statements saying they hire local employees and provide economic benefits to locals. The Ecuadorian websites had the lowest percentage (60\%); this may be due to the assumption that because they are based in Ecuador they would naturally hire local employees and provide local economic benefits. However, only $20 \%$ of the websites mentioned providing sociocultural benefits to locals. Some greenwashing may be evident here, since all of the operators did not mention hiring local employees, which is one of the key elements of ecotourism. Ecotour operators should be sensitive to this issue, and both hire local employees and place that information on their websites.

Minimal impact on and presentation of local (indigenous) culture and locally appropriate scale and design for lodging, tours and attractions are required to meet ecotourism standards. One hundred percent of the websites provided information that the number of visitors per tour is restricted. As stated earlier, this is a requirement of the Galapagos National Park.

What sustainable practices does the company engage in? Greenwashing is evident when it comes to sustainable practices. Only $20 \%$ of the websites mentioned home office environmental practices, less than half (47\%) said they purchase carbon offsets or engage in carbon neutral policies, and only $40 \%$ mentioned recycling, minimizing waste, and engaging in energy self-sufficient practices on the cruise ship during the tour. Only one company (Ecuadorian) is eco-certified through an outside, performance-based audit. While the companies may actually engage in these practices, their websites do not specifically mention them. Because an increasing number of ecotourists are researching and booking their trips online, it is important for ecotourism operators to include their sustainability practices on their websites. 
As the online travel market continues to grow, it is important that tour providers communicate effectively to their potential customers. One way to do this is to expand the types of social media used on the webpage rather than relying primarily on newsletters. Opportunities include Facebook, Twitter, podcasts and live chats.

Future research should focus on examining "nature-based" and "adventure" tourism in comparison to "ecotourism." Because many tour operators may not differentiate among the three, some nature and adventure tours may actually be ecotours. "Voluntourism" should also be explored as a subset to ecotourism.

\section{AUTHOR INFORMATION}

Donald R. (Don) Self is Distinguished Teaching Professor and Lowder/Weil Chair at Auburn University Montgomery (USA). He received the DBA degree from Louisiana Tech University in 1977 and has been a university teacher since 1970. He has received various teaching and research awards including the SherwinWilliams Distinguished teaching award from the Society of Marketing Advances.

Don served ten years as the founding editor of the Journal of Non-profit and Public Sector Marketing and served as Associate Editor of the Journal of Marketing and the Journal of Professional Selling and Sales Management. He has edited or co-edited seven books.

Dr. Robin Self, Professor of Management, has been a member of the Alabama State University faculty since 1991. She has degrees from the University of Georgia (BA - Communications 1978, MA - Communications 1981) and Georgia State University (Ph.D. - Management, 1991). Prior to joining Alabama State University, she taught at the University of Georgia and Georgia Southern University. Dr. Self has over 30 articles and conference papers in the areas of organization commitment and socialization, health care marketing, strategy, and culture including publications in the Journal of Applied Psychology, Journal of Management, Journal of Managerial Issues, and Health Marketing Quarterly. She has received several awards for teaching and research.

Janel Bell Haynes is an eighteen year communications, and marketing veteran with unique skills in project management, sales, and fundraising. A collegiate adjunct instructor for more than ten years she has held positions in the education, government, corporate and private sectors. Her specific and most recent experience includes strategic communications and media planning for a comprehensive regional university. Her professional career began as a hospitality and tourism professional in sales and marketing; currently she is a full-time instructor of marketing and acting chair for the Business Administration Department in the College of Business at Alabama State University.

\section{REFERENCES}

1. Adamson, J. (2005, May 28). It isn't easy being green. Sydney Morning Herald, p. 1.

2. Baker, N. (2005, December 10). Travel guilt free: Eco traveler know your greens. The Guardian (London). Guardian Newspapers Limited, p. 6.

3. Batta, R. N. (2006). Evaluating ecotourism in mountain areas: A study of three Himalayan destinations. International Review for Environmental Studies, 6 (1), 41-62.

4. Beam, A. (2007, February 4). Ecotourism goes urban. The Boston Globe, p. M1.

5. Brazil, M. (2000, December 19). Eco-terrorism threatens Galapagos natural treasures, eco-tourism. The Japan Times Online.

6. Chenu, M. (2007, November 18). Tread lightly-ecotourism NSW tourism awards. The Sun Herald (Sydney, Australia), John Fairfax Publications, p. 6.

7. Choo, H., \& Jamal, T. (2009). Tourism on organic farms in South Korea: A new form of ecotourism? Journal of Sustainable Tourism, 17(4), 431-454.

8. $\quad$ Cissel, S. (2009, April). Marketing through web sites. American Nurseryman, p. 34-37.

9. Clayton, M. (2004, November). When ecotourism kills. The Christian Science Monitor, p. 13.

10. Clifton, J., \& Benson, A. (2006). Planning for sustainable ecotourism: The case for research ecotourism in developing country destinations. Journal of Sustainable Tourism, 14 (3), 238-254.

11. Conservation challenges in the Galapagos. (2009). Adventure Life. www.adventurelife.com/articles/galapagos-conservation-177 
12. Constantineau, B. (2007, September 28). Going real green: Explosion of ecotours offer real and ersatz vacations. National Post, p. SR7.

13. Cox, S. (2007, August 4). Brave new world of tourism. The Christchurch Press Company Limited, p. 15.

14. Dolnicar, S., Crouch, G., \& Long, P. (2008). Environmental-friendly tourists: What do we really know about them? Journal of Sustainable Tourism, 16 (2), 197-210.

15. Ecotourism. (2009, September 23). Africa News. All-Africa, Inc.

16. Ecotourism Credentials: Green - or just a bit shady? (2007, May 25). Travel Trade Gazette UK \& Ireland.

17. Ecuador Tourism. (2009). www.ecuador.us/tourism

18. Ecotourism tries to ensure local population will reap its benefits. (2008, January 28). Toronto Star, p. AA02.

19. Elston, J. (2007, October 27). Tourism goes true green. West Australian Newspapers Limited, p. 14.

20. Fosbery, S. (2006, September 16). In praise of green. Weekend Australian, p. 3.

21. Galapagos and you. (2009). http://galapagos-and-you.com/index

22. Gray, N. J., \& Campbell, L. M. (2007). A decommodified experience? Exploring aesthetic, economic and ethical values for volunteer ecotourism in Costa Rica. Journal of Sustainable Tourism, 15 (5), 463-482.

23. Goeldner, C. R., \& Ritchie, J.R. (2009). Tourism: Principles, Practices, Philosophies. (11 ${ }^{\text {th }}$ ed). New Jersey: Wiley and Sons.

24. Hickman, L., (2006, May 20). Travel: TheBigIssue2: Is the future green? Guardian Newspapers Limited, p. 6.

25. Honey, M., \& Stewart, E. (2002). Introduction in M. Honey (ed.) Ecotourism and Certification (pp. 1- 29). Washington DC: Island.

26. Kaplan, M. (2009, April 11). Ecotourism to blossom. Weekend Australian, Nationwide News Pty Limited, p. 44.

27. Ketchel, M. (2007, November 26). Rally cry to green tourism. The Courier Mail (Australia). Nationwide News Pty Limited, p. 18.

28. Kim, Seong-il. (2009, April 30). Green growth: Korea's new strategy. The Korea Herald.

29. Kuchment, A. (2008, July 21). Beyond Backpacking; First there was ecotourism. Then came sustainable travel and green hotels. What's in your suitcase? Newsweek, p. 44.

30. Kwan, P., Eagles, P., \& Gebhardt, A. (2008). A Comparison of ecolodge patrons' characteristics and motivations based on price levels: A case study of Belize. Journal of Sustainable Tourism, 16 (6), 698718.

31. L'Express. (2006, June 13). Ecotourism: Before thinking about encouraging more tourists to visit, the government should make sure the industry is sustainable. Africa News, AllAfrica, Inc.

32. Leach, S. L. (2004, December 22). Travelers who strive to do no harm. Christian Science Monitor, p. 15.

33. May, K. (2006, October 27). Travel Weekly: The Choice of Travel Professionals (00494577) [serial online]. Available from Business Source Premier, Ipswich, MA.

34. Medina, L. K. (2005). Ecotourism and certification: Confronting the principles and pragmatics of socially responsible tourism. Journal of Sustainable Tourism, 13 (3), 281-295.

35. Mercer, D. (1996). Ecotourism. Geodate, 9(1), 1. http://search.ebscohost.com

36. Mitchell, L. (2008, February 17). Getaway unplugged: ECO Life. Sunday Age (Melbourne, Australia), The Age Company Limited, p. 21.

37. Nash, S. (2009). Ecotourism and other invasions. Bioscience, 59 (2), 106-110. http://search.ebscohost.com, doi:10.1525/bio.2009.59.2.3

38. Natural Habitat Adventures (2009). wwwnathab.com

39. Pfeiffer, C. (2009, September 6). Top eco breaks. Australia Telegraph, p. 6.

40. Powell, R. B., \& Ham, S. H. (2008). Can ecotourism interpretation really lead to pro-conservation knowledge, attitudes and behavior? Evidence from the Galapagos Islands. Journal of Sustainable Tourism, 16 (4), 467-489.

41. Responsible Tourism. (2007, July 21). The Business Times Singapore.

42. Romeril, M. (1985). Tourism and the environment - towards a symbiotic relationship. International Journal of Environmental Studies, 25, 215-218.

43. Schumacher, H. J. (2007, June 15). Let's Talk Europe: Ecotourism. BusinessWorld, p. S1/6.

44. Shaddick, C. (2008, June 5). Online changes how holidaymakers behave. New Media Age, p. 10. 
45. Silva, G., \& McDill, M. (2204). Barriers to ecotourism supplier success: A comparison of agency and business perspectives. Journal of Sustainable Tourism, 12(4), 289-305.

46. Sinclair, J. (2009). Ecotourism-An overview. http://www.sinclair.org.au

47. Special Report: Travel Marketing. (2006, September 1). www.bandt.com.au, p. 16-18.

48. Stem, C.J., Lassoie, J.P., Lee, D.R., \& Deshler, D.J. (2003). How 'eco' is ecotourism? A comparative case study of ecotourism in Costa Rica. Journal of Sustainable Tourism, 99 (4), 322-347.

49. Stronza, A., \& Pegas, F. (2008). Ecotourism and conservation: Two cases from Brazil and Peru. Human Dimension of Wildlife, 13, 263-279.

50. Su, S. (2002). Ecotourism in the Galapagos: A Sustainable Relationship?, http://www.stanford.edu/class/antsci/2002_galapagos_website/susanpaper.htm

51. Thomson, B. (2000). Beyond Ecotourism: Going Native. Earth Island Journal, 15(3), 27.

52. Tourism Trends. (2008). World Almanac \& Book of Facts, 78. http://search.ebscohost.com

53. Travel agents despair. (2006, April 6). Caribbean Business.

54. Travel and tourism: Misuse of 'Eco' tag gives tourism a bad name. (2005, December 5). AllAfrica, Inc.

55. USAID launches ecotourism development program. (2008, July 17). The Daily Monitor.

56. Wallace, G., \& Pierce, S. (1996). An evaluation of ecotourism in Amazonas, Brazil. Annals of Tourism Research, 23 (4), 843-873.

57. Weaver, D. (2002). Asian ecotourism : patterns and themes. Tourism Geographies, 4 (2), $153-172$.

58. $\quad$ www.ecotourism.com, Retrieved October 14, 2009

59. Www.world-tourism.org. Retrieved October 14, 2009 
NOTES 